
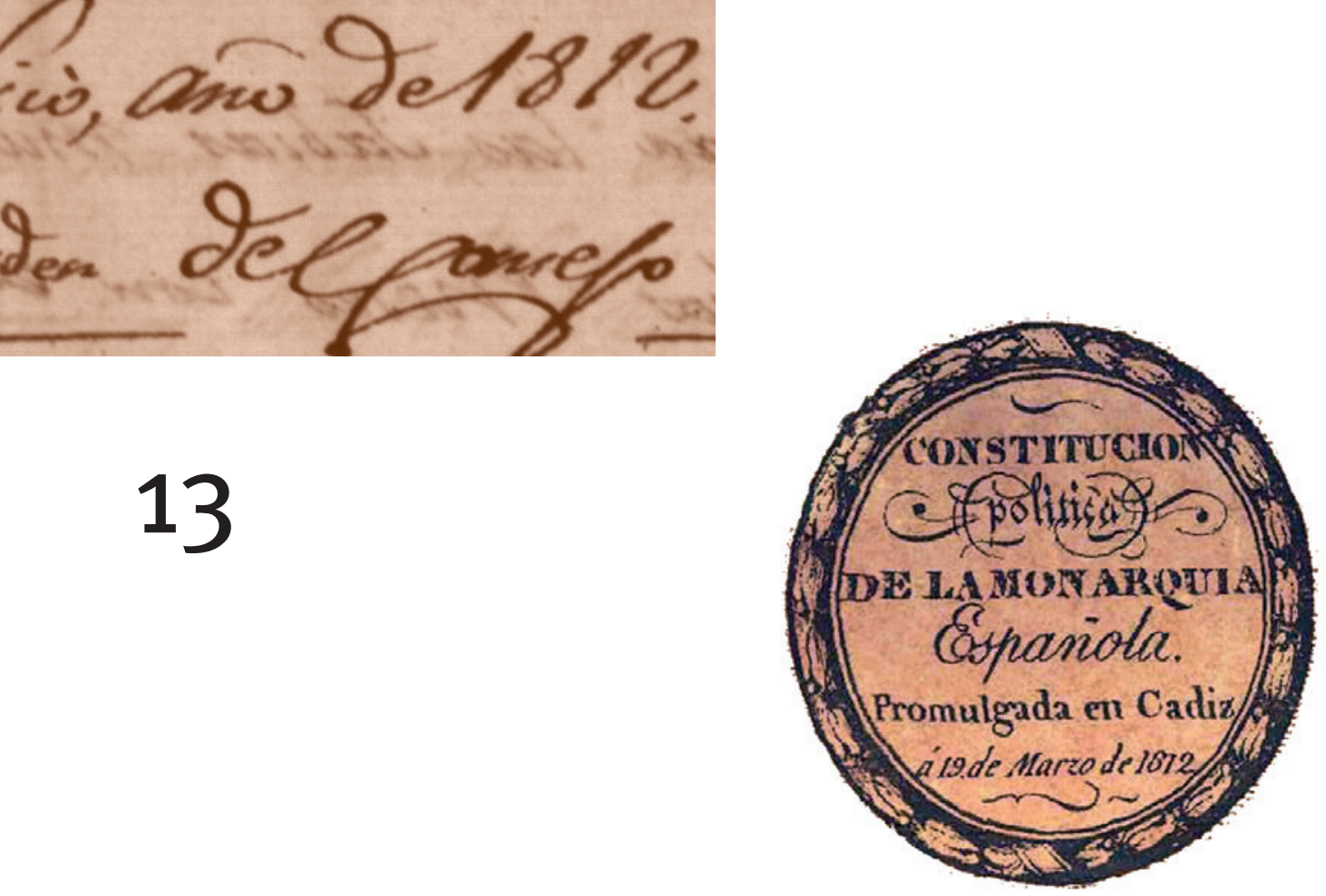

13

romulgada en Cadiz
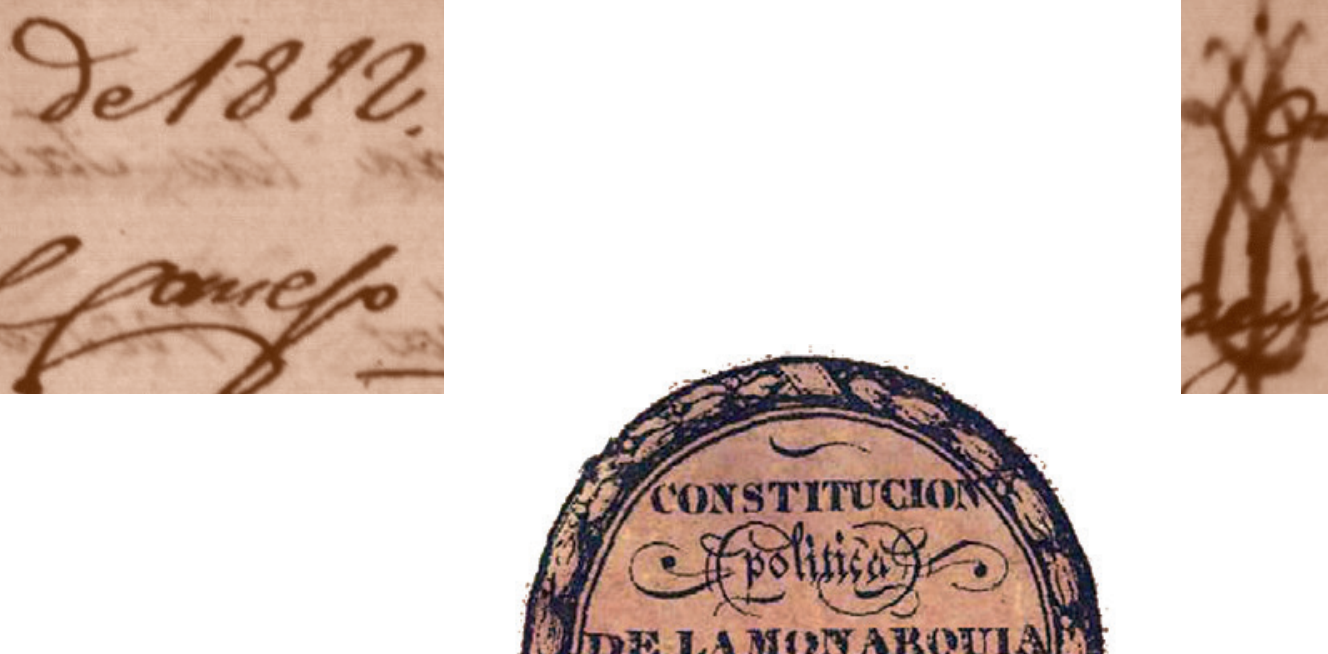



\section{Colección $\mathbf{I m u d}$ \\ n. ${ }^{\text {13 }}$}

\section{LA PROVINCIA DE LA MANCHA Y LA CONSTITUCIÓN DE 1812}





\section{Carlos Chaparro Contreras \\ e Isidro Sánchez Sánchez (eds.)}

\section{LA PROVINCIA DE LA MANCHA Y LA \\ CONSTITUCIÓN DE 1812}

Ediciones de la Universidad

de Castilla-La Mancha

Cuenca, 2021 
LA PROVINCIA de La Mancha y la Constitución de 1812 / editores, Carlos Chaparro Contreras, Isidro Sánchez Sánchez.- Cuenca : Ediciones de la Universidad de Castilla-La Mancha, 2020

341 p. ; 24 cm.- (Almud ; 13)

ISBN 978-84-9044-311-8

1. España - Constitución - 1812 2. Castilla-La Mancha - Historia I. Chaparro Contreras, Carlos, ed. lit. II. Sánchez Sánchez Isidro, ed. lit. III. Universidad de Castilla-La Mancha, ed. IV. Serie

342.4(460)"1812"

946.028

1DSE-ES-G

NHD

(C) de los textos e imágenes: sus autores.

(C) de la edición: Universidad de Castilla-La Mancha.

Edita: Ediciones de la Universidad de Castilla-La Mancha y Centro de Estudios de Castilla-La Mancha.

Colección Almud n. ${ }^{\circ} 13$.

Diseño de la colección:

C.I.D.I. (Universidad de Castilla-La Mancha).

unte Unión de Edtorlales
Universitarias Españolas nacional.

Esta editorial es miembro de la UNE, lo que garantiza la difusión y comercialización de sus publicaciones a nivel nacional e inter-

ISSN: $1988-0979$

I.S.B.N.: 978-84-9044-311-8 (Edición impresa)

I.S.B.N.: 978-84-9044-434-4 (Edición electrónica)

D.O.I.: http://doi.org/10.18239/alm_2021.13.00

D.L.: CU 248-2019

Composición: Compobell S.L.

Impresión: Gráficas Izquierdo

Hecho en España (U.E.) - Made in Spain (U.E.)

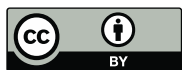

Esta obra se encuentra bajo una licencia internacional Creative Commons CC BY 4.0.

Cualquier forma de reproducción, distribución, comunicación pública o transformación de esta obra no incluida en la licencia Cretative Commons CC BY 4.0 solo puede ser realizada con la autorización expresa de los titulares, salvo excepción prevista por la ley. Puede Ud. acceder al texto completo de la licencia en este enlace: https://creativecommons.org/licenses/by/4.0/deed.es 


\section{ÍNDICE}

Presentación ..................................................................................

Gabino Marco Solera, Carmen María Montalbán Martínez y Antonio Ruiz Lucas

Las Cortes y la Constitución de Cádiz: contenidos sociales y esperanzas populares

Juan Sisinio Pérez Garzón

La Constitución de 1812

Enrique Belda Pérez-Pedrero

Guerra y revolución en La Mancha Ángel Ramón del Valle Calzado

El Partido de Alcaraz a finales del Antiguo Régimen

65 Carmen Hernández López y Francisco García González

"Napoleón emperador" y el destino del Partido de Almagro......... José Gregorio Cayuela Fernández

La Mancha, 1812: El partido judicial de Villanueva de los Infantes Lucía Crespo Jiménez

Representación y educación político-popular en las ceremonias y fiestas de proclamación y jura de la Constitución de 1812 en La Mancha

Carlos Chaparro Contreras

La crisis del Antiguo Régimen en La Mancha (1787-1808). El caso de Villanueva de los Infantes y su partido.... Carlos Javier Rubio Martínez 
Los manchegos que auparon a la "Pepa"

Enrique Jiménez Villalta

Almadén y la Constitución de Cádiz (1812-1814)

245

Julián Prior Cabanillas

El padre Agustín de Castro y la prensa periódica

273 Isidro Sánchez Sánchez 


\title{
ALMADÉN Y LA CONSTITUCIÓN DE CÁDIZ (1812-1814)
}

\author{
JULIÁN PRIOR CABANILLAS \\ HISTORIADOR Y ARCHIVERO
}

\section{INTRODUCCIÓN: LA OCUPACIÓN FRANCESA DE ALMADÉN DURANTE LA GUERRA DE LA INDEPENDENCIA (1810-1812)}

Al igual que en otros muchos lugares de la Península, como inicial reacción contra el ocupante francés se creó en Almadén una Junta de Gobierno en 1808, concretamente el día 10 de junio, en un momento en que multiplicaban en la provincia de La Mancha las primeras acciones bélicas contra el invasor napoleónico ${ }^{1}$.

Los objetivos de dicha Junta de Gobierno de Almadén fueron el mantenimiento del orden público en la región, la contribución a la defensa de la Nación frente a las tropas napoleónicas y a favor del rey Fernando VII y, muy especialmente, el sostenimiento económico de la localidad y sus minas de mercurio (mineral necesario para la explotación a gran escala de la plata americana, tradicional fuente de ingresos para la monarquía hispana) $)^{2}$.

1 La Junta de Almadén tuvo un carácter local-institucional, puesto que representaba tanto los intereses de la villa como los de sus Reales Minas de mercurio, estando integrada en su origen mayoritariamente por oficiales de la dirección del establecimiento minero, miembros del Ayuntamiento, eclesiásticos y militares, encabezados por el superintendente de las Reales Minas y gobernador de Almadén, Pedro Hernando (esto es, miembros de la clase dirigente del Antiguo Régimen, sin que encontremos en ella a ningún elemento "popular" ni de ideas expresamente "liberales"). Los "cuadernos de actas" de la Junta de Gobierno de Almadén pueden consultarse en los legajos 37 (cuadernos primero y segundo, de junio a septiembre de 1808, y de septiembre de 1808 a septiembre de 1811, respectivamente) y 38 (cuaderno tercero de actas de la Junta local de Gobierno, de agosto de 1811 a septiembre de 1812) del Archivo Histórico Municipal de Almadén (en adelante, AHMA).

2 Con el saqueo de la ciudad de Córdoba el día 7 de junio de 1808 por parte de las tropas francesas del general Dupont quedó cortado de raíz el envío de la consignación mensual de medio millón de reales que la villa manchega tenía concedida sobre la tesorería de aquella ciudad desde 
Pese a los ímprobos esfuerzos que se van a realizar, las labores de fundición en las Reales Minas de mercurio de Almadén tuvieron que ser detenidas el mismo año 1808 por falta de medios económicos, quedando reducidas las tareas al imprescindible mantenimiento y desagüe de los pozos, para evitar así un deterioro tan grave en las instalaciones que hiciera imposible su puesta en funcionamiento una vez finalizada la contienda.

La situación de impasse que se instaló en la región de las minas de Almadén en el verano de 1808, tras la victoria de las tropas aliadas en la batalla de Bailén (que impidió a los franceses ocupar el sur peninsular en ese momento), se va a ver truncada cuando a comienzos de 1810 José I se propone ocupar nuevamente Andalucía, una de cuyas vías de acceso desde el centro peninsular era precisamente el llamado "camino real de la plata” que atraviesa Sierra Morena a la altura de Almadén. Tal vía va a ser la elegida en su camino hacia Andalucía por los soldados del mariscal Victor, que entran por primera vez en la villa manchega el día 15 de enero de 1810, sin encontrar resistencia alguna (las tropas del general Zerain encargadas de defender Almadén tras la derrota de los ejércitos fernandinos en Ocaña en noviembre de 1809 se habían retirado el día anterior, y con ellas el gobernador y superintendente Pedro Hernando).

En todo caso, en enero de 1810 las autoridades francesas no establecieron una guarnición fija en Almadén, aunque sí nombraron un gobernador y superintendente de las Minas, el coronel Francisco Cabello, que estableció su residencia en la localidad cercana de Manzanares, una de las plazas fuertes de las tropas francesas en la región y sede de la Prefectura josefina de La Mancha ${ }^{3}$. Pese al nombramiento de Cabello

las décadas centrales del siglo XVIII. A partir de ese momento, la principal preocupación de las autoridades de la villa -y especialmente de su Junta de Gobierno, erigida sólo tres días después de los sucesos de Córdoba- será conseguir los fondos económicos suficientes para evitar la ruina del establecimiento minero y pagar a sus empleados y jornaleros.

3 Francisco Cabello y Mesa (1764-c.1835), natural de Fuenlabrada de los Montes (Badajoz), a pocos kilómetros de Almadén, es un polifacético personaje: emigrado a Perú en 1789, al año siguiente fundó (bajo el seudónimo Jaime Bausate y Mesa) el que se considera como primer diario publicado en América, el Diario de Lima curioso, erudito, económico y comercial (1790-1793). Posteriormente pasó a Buenos Aires (no sin antes haber conocido de cerca el funcionamiento de las explotaciones mineras peruanas, pues llegó a ser inversor de algunas de ellas), donde publicó el primer periódico impreso porteño, el Telégrafo mercantil, rural, político-económico e historiográfico del Río de la Plata (1801-1802). De vuelta a la Península, parece ser que estuvo presente en Madrid en los hechos del 2 de mayo de 1808 y también en la batalla de Bailén como coronel del ejército del general Castaños. Tras la entrada de Napoleón en Madrid a finales del mismo año 1808, Cabello pasaría al bando josefino, siendo uno de los funcionarios elegidos por José I en 1809 para difundir las ideas de pacificación y sumisión a la nueva dinastía en América. Parece ser que nunca llegó a realizar dicho viaje a las Indias, porque en el momento de ser nombrado superintendente de las Reales Minas de Almadén en los primeros días de enero de 1810 se encontraba en Madrid. En febrero del mismo año obtenía la Orden Real de España. En el verano de 1812 Cabello acompañará a José I en su retirada hacia Valencia, exiliándose al año siguiente a Francia, donde vivió como gramático, traductor y dramaturgo hasta su regreso a la Península en 1823 con los "Cien mil hijos 
(quien no se personó en la villa hasta finales de la primavera de 1812), la realidad era que la ausencia de un acantonamiento francés en Almadén durante los años 1810 y 1811 impidió el dominio efectivo de sus minas por parte del Gobierno josefino (control que correspondía en principio al mariscal Soult y su "Ejército del Mediodía", que no limitaba su área de influencia exclusivamente a Andalucía, sino que englobaba ciertas zonas de Extremadura y de La Mancha, como Badajoz y las Minas de Almadén, como garantía financiera y de control de las vías de comunicación con la Corte de Madrid) ${ }^{4}$.

A partir de enero de 1810 comienza un periodo complejo en Almadén, que podría ser calificado como de "dualidad institucional": habiendo visto cortada toda posible comunicación con la Junta Suprema fernandina refugiada en Cádiz y ausente desde el mismo momento de la ocupación francesa el superintendente y gobernador "titular" (Pedro Hernando), la villa quedaba un tanto abandonada a su suerte y en una situación de incertidumbre militar y política en cuanto a las lealtades hacia uno u otro bando se refiere. Así, si bien formalmente se encontraban bajo el control de las autoridades francesas (que, como hemos señalado, habían nombrado un gobernador y superintendente de la localidad a los pocos días de haber pasado por ella el mariscal Victor), durante los años centrales de la guerra las Reales Minas de Almadén siguieron siendo también "socorridas" por el bando fernandino, que nombró, por su parte y de forma paralela, otro gobernador y superintendente para el establecimiento, Juan Bautista Erro, estante en la villa albaceteña de Elche de la Sierra, donde se estableció durante buena parte de la guerra la Junta Superior de La Mancha, que él presidía ${ }^{5}$. Sin embargo, ninguno

de San Luis”, postulándose como defensor de Fernando VII. En Madrid pasará los últimos años de su vida, persiguiendo alguna pensión o retiro con sueldo que al parecer nunca conseguirá (A. de Ceballos-Escalera y Gila (marqués de La Floresta), y A. Arteaga y del Alcázar, La Orden Real de España (1808-1813), Madrid, Montalbo, 1997, p. 118; M. P. Martini, Francisco Antonio Cabello y Mesa, un publicista ilustrado de dos mundos (1786-1824), Buenos Aires, Instituto de Investigaciones sobre Identidad Cultural de la Universidad del Salvador, 1998; J. Torre Revello, El libro, la imprenta y el periodismo en América durante la dominación española, Buenos Aires, Facultad de Filosofía y Letras, 1940, especialmente pp. CCXXI-CCXXVII; M. Artola, "Los afrancesados y América”, en Revista de Indias, núm. 37-38 (1949), pp. 541-567).

4 J. M. Lafon, L'Andalusie et Napoléon. Contre-insurrection, collaboration et résistances dans le midi de l'Espagne (1808-1812), Paris, Nouveau Monde, 2007, pp. 36-37.

5 El día 6 de marzo de 1811, y en sustitución del huido Pedro Hernando, la Regencia fernandina nombrará "gobernador en comisión y superintendente interino de Almadén y sus Reales Minas" a Juan Bautista Erro, intendente de la provincia de La Mancha, nombramiento del que no se tomará razón en Almadén hasta el día 24 de septiembre de ese año 1811 (Archivo Histórico Nacional, Fondos Contemporáneos, Minas de Almadén [en adelante AHN, FC-Minas_Almadén], leg. 1134, caja primera, documento 53 del año 1811). Como veremos, Erro no podrá trasladarse en persona a la villa hasta un año más tarde, concretamente hasta el 23 de septiembre de 1812 , unas pocas semanas después de haberla desocupado los franceses. Juan Bautista Erro Azpiroz (1773-1854), nacido en Andoain (Gipúzkoa), entró como alumno de la Academia de Minas de 
de los dos contendientes se decidió a establecer en esos años un destacamento militar permanente en la localidad, por temor a llevar consigo la destrucción de tan preciosa "joya" para el Estado.

Es más, en ausencia física de las autoridades nombradas de forma "paralela" por las dos partes enfrentadas, Cabello por el bando josefino y Erro por el fernandino, ambas confirmaron como gobernador y superintendente interino de Almadén a la misma persona, Juan de la Plazuela, el oficial de mayor rango de la Contaduría de las Reales Minas. Así, Plazuela va a ser la primera autoridad de facto en Almadén durante buena parte de la Guerra de la Independencia, como gobernador y superintendente interino y cabeza de la Junta local de Gobierno, que va a seguir siendo la principal valedora de la villa de Almadén y de sus Reales Minas durante el conflicto bélico, abandonando cualquier tipo de inclinación política hacia uno u otro bando y convirtiéndose en un organismo "técnico" cuyo único objetivo era asegurar que se llevasen a cabo los trabajos imprescindibles de desagüe y mantenimiento que evitaran la ruina de la explotación minera (ya que durante la contienda no era posible continuar con las labores metalúrgicas y de extracción del mercurio).

Esta situación de "tensa calma" y de "dualidad de jurisdicciones" vivida en Almadén y sus minas desde el primer paso por la villa de los soldados del mariscal Víctor camino a Andalucía a principios de 1810

\footnotetext{
Almadén en 1791, y ocupó posteriormente los cargos de contador principal de Rentas, Propios y Arbitrios de las provincias de Soria (1798) y la Mancha (1807), antes de ser nombrado intendente y presidente de la Junta de La Mancha en 1809 (como tal llegó a ser elegido en 1810 diputado para las Cortes Generales y Extraordinarias por el procedimiento para las provincias ocupadas en parte por los franceses, aunque las Cortes anularían su elección por no ser natural de la circunscripción). Durante la Guerra de la Independencia compaginó su cargo como intendente de La Mancha con el de superintendente de las Reales Minas de Almadén por el bando fernandino. Tras la contienda, llegó a ser intendente de Madrid (1814) e intendente del Ejército de Cataluña (1817). Durante el trienio liberal huyó a Francia, regresando a la Península en 1823 con los "Cien mil hijos de San Luis" (curiosamente, al lado de quien había sido también superintendente de Almadén durante la Guerra de la Independencia, Francisco Cabello y Mesa, este último por el bando josefino). Fernando VII lo nombró entonces ministro de Hacienda (cargo que ocupó del 26 de mayo al 2 de diciembre de 1823), e inmediatamente después consejero de Estado. En 1833 tuvo que huir a Londres, donde contactó con el bando carlista, en el cual alcanzó puestos de máxima responsabilidad. Su último destierro fue en Francia, con motivo del Convenio de Vergara de 1839, y allí murió en 1854. Durante su vida, Erro destacó también como autor de diversos estudios sobre la lengua vasca (J. Gárate, "Juan Bautista de Erro y Aspiroz”, en Revista de Estudios Vascos (Eusko-Jakintza), núm. 2 (1948), pp. 539-566; F. Arocena Arregui, Juan Bautista de Erro y Azpíroz, 1773-1854, San Sebastián, Diputación Provincial de Guipúzcoa, 1954; J. A. García Noblejas, "Don Juan Bautista de Erro y Azpiroz, político y presidente de la Junta de Gobierno de La Mancha durante la Guerra de la Independencia”, en Cuadernos de Estudios Manchegos, núm. 13 (1982), pp. 57-68; J. A. Casquero Fernández y M. A. Jaramillo Guerreira, "Nuevas aportaciones documentales para la biografía de Juan Bautista Erro. El archivo del marquesado de Grox", en Sancho el Sabio: revista de cultura e investigación vasca, núm. 5 (1995), pp. 339-358).
} 
va a cambiar radicalmente en enero de 1812, cuando la pugna por el control directo y efectivo de la explotación del mercurio, que podía reportar importantes beneficios a quien lograse hacerse de manera efectiva con el mismo, hizo que los soldados franceses a las órdenes del mariscal Soult, general en jefe del Ejército del Mediodía, ocupasen por segunda vez la villa de Almadén, estableciendo ahora una guarnición estable, fortificando el pueblo, tapiando y amurallando las calles más cercanas al establecimiento minero, incluyendo el castillo de Retamar, e intentando poner de nuevo en funcionamiento las minas ${ }^{6}$.

En todo caso, el intento del mariscal Soult de hacerse cargo directamente de la explotación de las minas de Almadén va a ser efímero, puesto que en agosto de ese mismo año 1812 las tropas francesas se van a ver obligadas a evacuar la región, debido al empuje de la ofensiva aliada encabezada por el general Wellington en el conjunto de la Península Ibérica. Así, el día 22 de agosto de 1812 cesaba en sus funciones Francisco Cabello, que procedía a abandonar Almadén a la mañana siguiente junto con los últimos elementos de las tropas francesas que habían ocupado la villa ${ }^{7}$.

Conocida por las autoridades fernandinas la noticia del inminente abandono de Almadén por parte de los soldados franceses, la Regencia del Reino refugiada en Cádiz daba la orden a Juan Bautista Erro de trasladarse inmediatamente a la villa "si se hallase evacuada por los enemigos, haciéndose cargo interinamente de su gobierno, para que proceda a establecer la tranquilidad entre aquellos empleados (...) [conocido el] estado de desavenencia y desconfianza recíproca en que se hallan los principales jefes de Almadén y varios subalternos”, tal y como señala la Orden de 22 de agosto de 1812, el mismo día que -como hemos vistose producía el "cese" de Francisco Cabello como superintendente nom-

6 I. Mansilla Muñoz (coord.), Almadén, apuntes históricos de la vida de un pueblo, Ciudad Real, Universidad Popular (Grupo de Estudios de Almadén y Comarca), 1997, p. 137. La ocupación militar de Almadén por parte de las tropas de Soult en el mes de enero de 1815 se enmarca en el intento de repeler la incursión en la provincia de La Mancha de la División profernandina del brigadier Pablo Morillo (unos 3.000 o 4.000 hombres), que tenía la intención de atacar a las guarniciones josefinas allí existentes y reunir nuevos reclutas y subsistencias (y que respondía a la llamada del general Castaños de llevar a cabo movimientos de "distracción del enemigo" de todas las formas posibles, tras conocerse a finales del año 1811 la noticia de la marcha de la Península de una gran parte de las fuerzas francesas que habían permanecido hasta entonces sobre la línea del Tajo, para preparar la campaña napoleónica de Rusia).

7 Así lo señala una noticia dada en Agudo el 28 de agosto, aparecida en la Gazeta de la Junta Superior de La Mancha del día 5 de septiembre: "Los [soldados franceses] del cantón de Almadén marcharon en la mañana del 23 a toda prisa, después de haber vendido todos sus efectos. Lo mismo han ejecutado los de la Puebla [de Alcocer], y todos se reúnen en Castuera, donde se juntará el conde de Erlon [general Jean-Baptiste Drouet] para retirarse a Córdoba". Recordemos que el 20 de agosto José I había tenido que abandonar Madrid ante el negativo desarrollo de la guerra para sus intereses. 
brado por el bando josefino y sólo un día antes de la salida efectiva de las tropas francesas de Almadén ${ }^{8}$. En dicha Orden, la Regencia insistía a Erro en que procediese de forma urgente a la remisión a Cádiz de la mayor cantidad de mercurio posible. En todo caso, Juan Bautista Erro no llegaría a la villa manchega hasta el día 23 de septiembre de 1812, un mes más tarde de recibir el mandato de la Regencia, y más de un año después de su nombramiento como gobernador y superintendente de Almadén y sus Reales Minas.

La llegada del superintendente y gobernador Erro a Almadén significó también el intento de reanudar las consignaciones económicas regulares a favor de la villa y sus Reales Minas. En este sentido, el 29 de septiembre de 1812, ya desocupada también la ciudad de Córdoba por los franceses, la Regencia del Reino acordó que la Tesorería de dicha ciudad volviese a remitir 500.000 reales mensuales a Almadén, como lo habían venido haciendo desde antes de la ocupación francesa9 ${ }^{9}$.

\section{La aplicación de la Constitución de Cádiz en Almadén (1812- 1814)}

Además de volver a poner en explotación las minas, prácticamente paralizadas desde el año 1808, y acelerar el envío de la mayor cantidad de mercurio posible al Gobierno fernandino establecido en Cádiz, la Orden de la Regencia de 22 de agosto de 1812 también compelía

8 Archivo General de Indias (en adelante, AGI), Indiferente, leg. 550, libro 1 ("Registro de decretos y órdenes generales y particulares relativas al fomento de las minas y canteras de las provincias de Ultramar", fols. 2r-4v).

9 AGI, Indiferente, leg. 550, libro 1, "Registro de decretos y órdenes generales y particulares relativas al fomento de las minas y canteras de las provincias de Ultramar", fol. 5; y AHN, FC-Minas_Almadén, leg. 187, caja primera, documento de 17 de octubre de 1812. La ciudad de Córdoba no pudo cumplir cabalmente dicha medida de manera inmediata, al sufrir ella misma una enorme escasez de recursos; y lo mismo ocurrió con otras prescripciones similares dirigidas a los intendentes de Granada, Jaén, La Mancha o Extremadura para que auxiliaran a las minas, cuya ejecución tienen que reclamar insistentemente las autoridades de Almadén. Todo ello hizo que la salida de las tropas francesas de la villa no supusiese la inmediata solución de sus problemas económicos, aunque a partir de los primeros meses de 1813 volvieron a funcionar los hornos de fundición de las minas, que no habían sufrido graves daños durante la guerra, reanudándose entonces los envíos regulares de azogue a Sevilla (el buen estado general del establecimiento será constatado por el sucesor de Erro en la Superintendencia, José Antonio Arenas, en su detallada visita girada al establecimiento junto a los directores, subdirectores, delineantes y otros empleados del mismo, los días 5 de agosto y siguientes de 1813; AHN, FC-Minas_Almadén, leg. 1711). Pese a la mejoría económica, en los años siguientes tuvieron que emigrar de Almadén muchos trabajadores de las minas, sufriendo el establecimiento las consecuencias de la falta de brazos ocasionada por la guerra, tanto que la fortificación de los pozos mineros se va a descuidar lamentablemente por las dificultades económicas todavía algún tiempo, llegando casi a paralizarse la explotación de nuevo en 1817 (J. M. Pontes y Fernández, Historia de la antigua ciudad de Sisapón, hoy Almadén del Azogue, Madrid, Imprenta de Enrique Rojas, 1900, p. 165). 
al nuevo gobernador y superintendente a que dispusiese que "se jure, publique y cumpla rigurosamente en la villa de Almadén y su distrito la Constitución política de la Monarquía, procediendo, con arreglo a lo que tienen decretado las Cortes y a lo que previenen las leyes, a la averiguación de la conducta de esos empleados con respecto a nuestros enemigos cuando permanecieron en aquel suelo".

Y así lo va a cumplir Juan Bautista Erro nada más llegar a Almadén: la Constitución sancionada en Cádiz el 19 de marzo de 1812 por las Cortes Generales y Extraordinarias se "proclamará" en la villa manchega el sábado 26 de septiembre de ese mismo año, jurándose al día siguiente en una función parroquial solemne celebrada al efecto, sucediéndose a continuación varios días repletos de festejos populares ${ }^{10}$.

Una de las primeras resoluciones adoptadas por Erro a su llegada a Almadén fue la de disolver la Junta de Gobierno instaurada en 1808 y que con tanto ahínco había trabajado a favor de Almadén y sus Reales Minas a lo largo del conflicto bélico, tanto cuando la región estaba controlada por las autoridades leales a Fernando VII como cuando fue ocupada por los franceses. Dicha resolución fue tomada por el superintendente al día siguiente de su llegada a la villa, el 24 de septiembre (aun antes de la proclamación de la Constitución), "no siendo ya de ningún modo necesarias las funciones de esta Junta"11.

Se procedió entonces a la formación del "Ayuntamiento Constitucional de Almadén del Azogue", de acuerdo con las previsiones establecidas por la Carta Magna aprobada en Cádiz. La reunión constitutiva del nuevo Consistorio se celebró el día 6 de octubre de 1812, efectuándose entonces la elección de su secretario "conforme al artículo 320 del Título VI de la Constitución”, cargo que recayó en José Ponce de León, quien había venido ejerciendo el mismo puesto en el Ayuntamiento josefino hasta ese momento ${ }^{12}$.

10 Véase en el anexo de este trabajo la transcripción del acta de la jura de la Constitución en Almadén, cuyo conocimiento agradezco sinceramente a Enrique Jiménez Villalta. Dos testimonios notariales de dicho acta se conservan en el Archivo del Congreso de los Diputados (en adelante, ACD); además, en los Diarios de Sesiones de las Cortes Generales y Extraordinarias referidos a los días 28 de noviembre de 1812 y 21 de agosto de 1813 se recogen sendos mandatos de archivar los testimonios de haberse publicado y jurado la Constitución en varias localidades, entre ellas Almadén.

11 Orden recogida en la última de las actas de la Junta de Gobierno de Almadén, fechada de 25 de septiembre de 1812, procediéndose ese día a su disolución efectiva y al cese de todos sus miembros (AHMA, leg. 38, Cuaderno tercero de actas de la Junta de Gobierno, fols. 229v-230r).

12 El acta de la reunión constitutiva del Ayuntamiento Constitucional, con la que se abre un nuevo libro capitular, comienza como sigue: "En la villa de Almadén, a 6 de octubre de 1812, habiéndose reunido en las casas consistoriales los señores alcaldes, regidores y procuradores sindicos que componen el nuevo Ayuntamiento Constitucional, excepto el Sr. regidor Arenas...". Firman el acta Pedro Rodríguez, Juan García de la Rubia, Manuel Carballido Falcón, José Ramírez Álvarez, Francisco Villar, Alejandro Manuel Mancebo, José Antonio del Rey, José Matías Ramírez y José Ponce de León (AHMA, leg. 38, Libro de actas del Ayuntamiento de Almadén de 1813, fol. 
Además de la supresión de la Junta local y de la formación de un nuevo Ayuntamiento, la proclamación de la Constitución en Almadén trajo consigo también un cambio sustancial en el sistema de gobierno de la localidad, que va a marcar la vida institucional de la villa durante los meses siguientes: el gobernador y superintendente va a perder buena parte de las funciones que venía ejerciendo desde antiguo a favor de una figura de nueva planta, el juez de letras del partido de Almadén (también llamado simplemente "juez de letras”, “juez de partido" o "juez de primera instancia" $)^{13}$.

En este sentido, mediante un oficio fechado en Cádiz el 29 de septiembre de 1812, la Regencia del Reino comunicaba al secretario de despacho de Gracia y Justicia, Antonio Cano Manuel Ramírez de Arellano, entre otras cosas, la necesidad del nombramiento de un juez de primera instancia para la villa de Almadén, con el fin de unificar la administración de justicia del establecimiento minero con el sistema general que se estaba implantando en todas las provincias, un juez "que obre según las facultades que se designan en la Constitución, respecto de que ejerciendo

\footnotetext{
1). En la portada de dicho libro de actas puede leerse lo siguiente: "Libro de los acuerdos del Ilustre Ayuntamiento Constitucional de esta villa que comprende desde principios de octubre del presente año [1812] hasta fin de diciembre de 1813”). Apenas un mes después de su primera reunión, el Ayuntamiento Constitucional mostraba su interés en poder contar con una sede más a propósito para llevar a cabo las funciones que le otorgaba la Carta Magna: "Teniendo presente la indecencia y estrechez de las casas consistoriales (...) y siendo urgente por otra parte la necesidad de fijar en su fachada una lápida que exprese 'Plaza de la Constitución', según las órdenes del supremo Gobierno, acordaron se consulte este punto inmediatamente con el caballero intendente de la provincia, gobernador en comisión del establecimiento [Juan Bautista Erro], a fin de que permita la construcción de otras en el edificio coliseo situado en la plaza de San Juan, perteneciente a los propios, como sitio el más a propósito y donde sin costes de consideración pueden formarse muy capaces y con las oficinas correspondientes" (Acuerdo de 11 de noviembre de 1812; AHMA, leg. 38, Libro de actas del Ayuntamiento de Almadén de 1813). El día 15 de mayo de 1813 se acordaba "que inmediatamente se habilite en el coliseo a lo menos una pieza capaz y proporcionada para casas consistoriales", trasladando allí el archivo y los armarios y estanterías necesarios para la celebración de las reuniones del Ayuntamiento, "sin perjuicio de ampliarlas cuando lo permitan las circunstancias" (ídem).

13 El "juez de letras" era una institución prevista en los artículos 273 y 274 de la Constitución de Cádiz (incluidos en el capítulo I, "De los tribunales", de su título V, "De los tribunales y de la administración de justicia en lo civil y criminal”), que establecían lo siguiente: "Artículo 273. Se establecerán partidos proporcionalmente iguales, y en cada cabeza de partido habrá un juez de letras con un juzgado correspondiente. Artículo 274. Las facultades de estos jueces se limitarán precisamente a lo contencioso, y las leyes determinarán las que han de pertenecerles en la capital y pueblo de su partido, como también hasta de qué cantidad podrán conocer en los negocios civiles sin apelación”. Según la primera división territorial en partidos judiciales de la Península, aprobada por Real Decreto de 21 de abril de 1834, el Partido Judicial de Almadén abarcaba las siguientes localidades: Agudo, Alamillo, Almadén, Almadenejos, Castilseras, Chillón, Fuencaliente, Gargantiel, Saceruela, San Benito y Valdemanco.
} 
anteriormente estas funciones el gobernador [y superintendente] político y económico son incompatibles en el día la reunión de ambos cargos"14.

Para ocupar el cargo de juez de partido de Almadén se barajaron nombres como el de Antonio Grijalba y Verdes (asesor de las Reales Minas) o el de José Tomás Cortines (que había sido asesor interino y juez conservador de la dehesa de Alcudia, cargo ya extinguido), aunque finalmente la Regencia del Reino va a nombrar, mediante Real Orden de 2 de octubre de 1812, a Juan María Ruano para dicho puesto de "juez interino de esta villa, con la prevención entre otras cosas de que se traslade a ella inmediatamente para administrar justicia en lo civil y criminal conforme a lo resuelto por las Cortes Generales y Extraordinarias del Reino", nombramiento del que se toma constancia en el libro de acuerdos del Ayuntamiento de Almadén el 26 de octubre ${ }^{15}$. En ese momento, como señala un documento municipal, "publicada la sabia Constitución de la Monarquía española en 1812, electos los alcaldes en el modo y forma que prescribe su Título VI, y nombrado juez de primera instancia para dicha villa y su partido, quedó despojado el superintendente de la jurisdicción que antes ejercía, no sólo en los negocios gubernativos sino en los administrativos" 16 .

Como consecuencia de todo ello, el gobernador y superintendente de la villa, Juan Bautista Erro, hubo de dar traslado al nuevo juez de primera instancia (aunque no sin ciertas reticencias) de las causas que se seguían sobre la conducta que las autoridades de Almadén y de sus Reales Minas habían tenido durante la ocupación francesa, procedimientos que Erro había iniciado "en calidad de único juez del pueblo" hasta ese momento (pues así lo era de acuerdo con la Orden de la Regencia de 22 de agosto de 1812, ya citada, y con una provisión dictada al respecto por la Chancillería de Granada, establecida por aquel entonces en Alicante) $)^{17}$.

14 AGI, Indiferente, 550, libro 1, "Registro de decretos y órdenes generales y particulares relativas al fomento de las minas y canteras de las provincias de Ultramar y la Peninsula", fols. $5 \mathrm{v}-6 \mathrm{r}$.

15 AHMA, leg. 38, Libro de actas del Ayuntamiento de Almadén de 1813. Ruano tomó posesión de su cargo el día 30 de octubre, circulándose inmediatamente la noticia a las localidades cercanas de Chillón, Alamillo, Almadenejos y Gargantiel, que quedaban también dentro de su ámbito jurisdiccional como "anejas" a la villa de Almadén.

16 AHN, FC-Minas_Almadén, libro 1065.

17 Además de haber principiado tales causas judiciales, el superintendente Erro había dictado una disposición (el día 1 de octubre de 1812) ordenando "cesar en el ejercicio de sus destinos y goce de sueldos los sujetos a quienes los confió el que se titulaba gobernador y superintendente de este real establecimiento por nombramiento del intruso Gobierno", y encargando al contador que a todos los empleados que se hallasen en dicho caso "les haga saber que quedan separados de sus respectivos encargos y con la obligación de restituir las cantidades que indebidamente hayan recibido por dichos destinos" (AHN, FC-Minas_Almadén, leg. 337, caja primera). 
Un informe del juez de partido Ruano fechado el 4 de diciembre de 1812 , en que contestaba a la cuestión de "si alguno o algunos de los empleados públicos de este establecimiento [las Reales Minas de Almadén] tiene causa criminal pendiente en su juzgado", nos da a conocer el listado de procesos abiertos en ese momento:

\begin{abstract}
“A D. Diego de Larrañaga, director de estas Minas, le tengo principiada sumaria por infidencia; a D. Agustín de Ugena, subdirector, por el mismo delito; a D. Juan Manuel del Villar, por aparecer autor de un libelo sedicioso; a D. Miguel de Guevara [oficial de la Contaduría de las Minas], por indicado en haber tenido inteligencia criminal con los enemigos y mal manejo de fondos públicos, y ser tachado en la opinión pública; sin resultar por ahora ningún otro empleado, pues aunque D. Francisco de la Garza, teniente gobernador de Almadén, está inculcado con Guevara en algunos hechos, no resultan aún méritos para graduarle reo, ni he principiado causa contra él”18.
\end{abstract}

Entre dichos procedimientos seguidos por el delito de infidencia al rey Fernando VII tras la proclamación de la Constitución en Almadén ${ }^{19}$, el referido al subdirector del establecimiento, Agustín de Ugena, va a ser el más complejo, pues en él se van a ver también involucrados de una u otra forma buena parte de las personas que habían ocupado los más altos cargos en las Reales Minas de Almadén durante la ocupación francesa, incluidos el superintendente Juan Bautista Erro y su asesor letrado, José Antonio Arenas.

El proceso contra Ugena se había abierto a instancias de Martín Lorenzo de Cabo, oficial de la Contaduría, quien desde el mismo momento en que las tropas francesas hubieron desocupado Almadén cargó contra el subdirector por colaboración con el mariscal francés Soult, y por "las vejaciones que le ha hecho sufrir (...) por haberle denunciado ante los enemigos como fiel servidor del Gobierno legítimo" ${ }^{20}$. En virtud

18 Informe comprendido en la correspondencia mantenida entre los días 23 de noviembre y 7 de diciembre de 1812 entre el secretario de Estado de Hacienda (de Ultramar), Cristóbal Góngora Delgado, el gobernador y superintendente de Almadén, Erro, y el juez de primera instancia de la villa, Juan María Ruano (AHN, FC-Minas_Almadén, leg. 110, caja segunda).

19 Según el Diccionario de la lengua castellana compuesto por la Real Academia Española, en su edición del año 1803, "infidencia" era la "falta de confianza y fe debida a otros". La infidencia no se configuraba como un delito claramente tipificado por la legislación española; en principio, los infidentes no eran propiamente traidores, pues habían faltado incidentalmente a la lealtad al rey con actos o expresiones que se consideraron inconvenientes, y habían sido denunciados por ello. No obstante esta indefinición jurídica o la levedad de las faltas, en aquellos años se llegaron a imponer sentencias muy graves por el delito de infidencia, llegando incluso a la pena de muerte.

20 Denuncia de Martín Lorenzo de Cabo fechada en Córdoba el día 6 de septiembre ("Expediente sobre quejas recíprocas entre Martín Lorenzo de Cabo y Agustín de Ugena y otros", AHN, 
de tal reclamación, advertido "del peligro que con la reunión y la fiesta del día señalado para publicar la Constitución en la villa de Almadén corría la seguridad de Ugena, y teniendo presentes las voces de 'mueran los traidores' de los días anteriores en que el intendente entró en aquel pueblo, y no dudando contra quién se dirigían”, el intendente de La Mancha y gobernador y superintendente en comisión en Almadén, Juan Bautista Erro, había encarcelado a Ugena el mismo día de proclamación de la Constitución (26 de septiembre de 1812).

Debido a estas actuaciones judiciales contra el subdirector Ugena $y$, fundamentalmente, a las que se muestran como poco imparciales maniobras del juez Juan María Ruano durante dicho procedimiento, la tensión entre las principales autoridades de la villa de Almadén y de sus Reales Minas aumentó durante todo el año 1813, hasta tal punto que el caso llegaría al conocimiento de las Cortes del Reino, donde se abrió una averiguación en abril de 1814 "sobre la exposición del juez de primera instancia de Almadén acerca de la causa formada al subdirector de aquellas minas" 21 .

De acuerdo con el Diario de Sesiones de las Cortes del día 3 de abril de 1814 , el juez Ruano había dictado sentencia en primera instancia en el pleito contra Ugena el 26 de febrero de ese año, absolviendo al subdirector de las Reales Minas de los cargos que se le imputaban y, a su vez, acusando al superintendente Erro y a su asesor letrado Arenas de "infracción de la Constitución" (en concreto de sus artículos 254, 287, 290, 293 y 300, relativos a la responsabilidad de los jueces por el ejercicio de su función y a las garantías de los reos en el momento de su detención), por haber éstos dictado orden de prisión "de forma irregular" contra Ugena en septiembre de 1812, acusación que dio pie a las Cortes para iniciar su "averiguación" parlamentaria 22.

La nota predominante durante dicho proceso tramitado en las Cortes fue la opinión claramente contraria a la figura del juez Ruano, a quien se tacha de "hombre díscolo y atropellado", dejándose entrever que era un "declarado protector de todos los procesados", e incluso se aconsejaba al presidente y demás señores de la Comisión de Infracción de las

FC-Minas_Almadén, leg. 1606, caja primera). Por orden de la Regencia, el día 29 de septiembre el asunto pasaba de la Secretaría de Estado de la Gobernación de Ultramar a la de Gracia y Justicia (AGI, Indiferente, 550, libro 1, "Registro de decretos y órdenes generales y particulares relativas al fomento de las minas y canteras de las provincias de Ultramar y la Peninsula", fols. 5v-6r).

21 ACD, Serie general, leg. 14, exp. 70.

22 Según el Diario de Sesiones de las Cortes ordinarias del día 27 de marzo de 1814, Juan María Ruano "ocurre a las Cortes manifestando las causales (sic) que pueden haber mediado para la queja que, según ha visto en el papel titulado 'El Universal', han dado varios vecinos de aquella villa contra el exponente por infracciones de Constitución, sobre que recayó la resolución de que 'justificasen más sus reclamaciones', y hace una relación de los sucesos ocurridos en el Almadén desde que entró a ejercer su juzgado de primera instancia”. 
Cortes -ante la que se seguía la "averiguación"- que repasasen bien los autos formados por él, "para que puedan entender quién es este juez que se queja de infracción de otro [el superintendente Erro] a quien no le incumbe juzgar" 23 . Finalmente, todas estas actuaciones parlamentarias van a quedar truncadas antes de llegar a su resolución, debido la vuelta al trono de Fernando VII y su anulación de todas aquellas instituciones puestas en pie por las Cortes en los años de la guerra.

Además del proceso contra el subdirector Ugena, entre las actuaciones abiertas en Almadén tras la proclamación de la Constitución de Cádiz de 1812 para "depurar" responsabilidades por las actuaciones durante la ocupación francesa, destaca también el extensísimo "expediente criminal" seguido en ante el mismo juez de letras sobre la conducta política de Miguel de Guevara, miembro de la Contaduría de las Minas, cuya sentencia en primera instancia -en la que se le da por libre de la acusación de "haber tenido inteligencia criminal con los enemigos y mal manejo de fondos públicos, y ser tachado en la opinión pública por su cercanía al espurio [gobernador josefino de Almadén] Cabello"- fue dictada por el juez Ruano el 11 de noviembre de 1813, exculpación confirmada el 22 de abril de 1814 por la Audiencia Territorial de Madrid ${ }^{24}$.

Se conocen menos datos, en cambio, sobre el procedimiento abierto por infidencia contra el director de las Reales Minas, Diego de Larrañaga, citado por Ruano en su relación de causas abiertas de 4 de diciembre de 1812. Sólo sabemos fehacientemente que a mediados de julio de 1814 Fernando VII resolvió que "en consideración al estado de pobreza a que se halla reducido [Diego de Larrañaga] (...) y al dilatado tiempo que lleva de servicio (...) se le satisfaga la mitad del sueldo de 18.000 reales que disfrutaba, ínterin se determina la causa que tiene pendiente", dinero que "se entregará a la persona que con poder suyo se presentare al pagamento" 25 .

23 También los miembros del Consistorio de Almadén se habían mostrado desconfiados ante la actitud de Ruano, y ya en junio de 1813 (meses antes de que la situación llegase a conocimiento de las Cortes) acordaron intimarle para que "inmediatamente cese en las funciones de su interino cargo" hasta que no jurase solemnemente la Constitución de Cádiz, amparándose en el Decreto de las Cortes Generales y Extraordinarias CCII, de 9 de octubre de 1812, sobre el nombramiento de los magistrados de las Audiencias y de los Jueces de primera instancia (acuerdo del día 2 de junio de 1813, AHMA, leg. 38, Libro de actas del Ayuntamiento de Almadén de 1813, fol. 40).

24 AHN, FC-Minas_Almadén, leg. 1606, caja primera. La sentencia de la Audiencia de Madrid fue notificada a las autoridades de Almadén el 20 de julio de ese mismo año 1814, dándose ejecución a la misma con la readmisión de Guevara en la Contaduría de las Minas el día 4 de agosto de 1814 y pagándole los atrasos debidos (AHN, FC-Minas_Almadén, leg. 1134, caja segunda, documento 49 de 1814; y leg. 1453, caja primera, documento 43 del año 1814).

25 AHN, FC-Minas_Almadén, leg. 1453, caja primera, documento 38 de 1814. J. M. López de Azcona señala que Diego de Larrañaga fue separado de su puesto de director del establecimiento minero de Almadén (para el que había sido nombrado por Real Orden de 19 de mayo de 1802) por orden de la Regencia de 27 de marzo de 1813 -siendo sustituido interinamente por Timoteo 
Por otra parte, aunque no se trate propiamente de un procedimiento por infidencia, se encuentra también en la misma línea de "purificar" los comportamientos seguidos durante el conflicto bélico el Informe sobre la conducta política de Pedro Hernando elaborado por el Ayuntamiento Constitucional de la villa en el verano de 1813 a instancias de la Regencia del Reino. Tras largas y tensas sesiones, los miembros del Consistorio no lograron ofrecer una imagen unánime de la persona que en el momento de la ocupación francesa era gobernador y superintendente de la villa y de sus Reales Minas, el coronel del Real Cuerpo de Ingenieros Pedro Hernando, que había huido junto al general Zerain ante el avance de las tropas del mariscal Víctor en la primera ofensiva francesa contra la villa en enero de 1810: para una parte de los munícipes, Hernando era un "egoísta pasivo que ha estado a la capa de la suerte (sic) para tomar uno u otro partido", y "no había dado muestra alguna" a favor de la causa fernandina, por lo que incluso llegan a proponer que se le retirara el grado de coronel y que fuera enviado al frente de guerra "en clase de soldado, para que con acciones distinguidas vuelva a merecer progresivamente ascensos, distinciones y recompensas".

Para otra parte de los miembros del Ayuntamiento, en cambio, el superintendente Hernando se había caracterizado por "su benevolencia, buen trato y humanidad con las gentes", destacando que "su fidelidad a la religión, a nuestro rey y a la patria" había sido "pública y notoria", además de que "su frecuencia en los Santos Sacramentos, buena educación en su familia y desinterés en su magisterio" hacía de su conducta "la más arreglada" 26 .

Por su parte, al resto de los empleados del establecimiento minero a quienes no se había abierto proceso por infidencia les fue de aplicación el Decreto de las Cortes Generales y Extraordinarias CCIX, de 14 de noviembre de 1812, que establecía las "reglas para la rehabilitación de los empleados que continuaron en sus destinos bajo el gobierno del rey intruso" (en desarrollo de una previsión recogida en los decretos CLXXXIV, de 11 de agosto de 1812, "Medidas para el mejor gobierno de las provincias que vayan quedando libres", y CXCII, de 21 de septiem-

\footnotetext{
Álvarez de Veriña-, pasando a vivir a Madrid; López de Azcona añade que su expediente se resolvió favorablemente para Diego Larrañaga el 6 de septiembre de 1814, quedando entonces repuesto en la Dirección de las Minas; en todo caso, parece ser que Diego de Larrañaga no volvería nunca a Almadén, pues murió en su residencia de la calle San Juan de Madrid en los primeros días de octubre de ese mismo año 1814, "abatido por la desgracia, envidia e ingratitud de las que fue víctima" ("Mineros destacados del siglo XVIII. Diego de Larrañaga y Gárate”, en Boletín Geológico y Minero, núm. 96-3 (1985), pp. 112-114). Tras su muerte en 1814, Diego de Larrañaga fue sustituido en el cargo de director de las Reales Minas de Almadén por su hermano, José Larrañaga.

26 AHMA, leg. 38, Libro de actas del Ayuntamiento de Almadén de 1813, fols. 54-70.
} 
bre del mismo año, "Medidas para asegurar la confianza de la Nación respecto de los empleados y otras personas públicas" ${ }^{27}$.

A tal fin, el Ayuntamiento Constitucional de Almadén remitió al Ministerio de la Gobernación la información requerida por el citado decreto de las Cortes de 14 de noviembre de 1812, siendo resuelto dicho expediente de rehabilitación de los trabajadores de las Reales Minas de Almadén por la Regencia del Reino en los primeros meses de $1813^{28}$.

\section{EPÍlOgo: el Regreso de Fernando VII AL TRONO EN 1814 y LA ReS- TAURACIÓN DE LA SITUACIÓN PREVIA A 1808}

No habían recuperado las Reales Minas de Almadén su actividad habitual ni vuelto aún del todo las cosas a su cauce después de la salida de los franceses de la localidad cuando otro hecho vino a desestabilizar nuevamente la situación en la villa: la anulación de la Constitución de 1812 y de toda la obra legislativa de las Cortes gaditanas por parte de Fernando VII (tras su vuelta a España después de un largo periodo de prisión en Francia), mediante los decretos promulgados en Valencia el 4 de mayo de 1814 (dados a conocer a través de su publicación en la Gaceta de Madrid del 12 de mayo).

27 Mediante el Decreto CCIX, de 14 de noviembre de 1812, las Cortes, "habiendo considerado el lastimoso estado de las provincias que ha desocupado el enemigo, la urgente necesidad de poner arreglo en el servicio público de ellas, y el júbilo y entusiasmo con que en las mismas se ha recibido y jurado la Constitución”, establecían que "los empleados públicos (...) que habiendo continuado en sus anteriores destinos bajo el Gobierno intruso, y no teniendo en el día causa criminal pendiente, ni habiendo sufrido sentencia por la que se les imponga pena corporal o infamatoria, se hubiesen mantenido fieles a la causa de la Nación, serán rehabilitados y repuestos en sus empleos anteriores, siempre que los ayuntamientos constitucionales de los pueblos en que los hayan ejercido (...) hagan expresa y formal declaración de que durante la dominación enemiga han dado pruebas positivas de lealtad y patriotismo, y gozado de buen concepto y opinión en el público". Un mes después de aprobado dicho decreto, el superintendente Erro, "preponderando la importancia del servicio que no puede fiarse por de pronto a otras manos que sustituyan a los [mineros] suspensos, ni menos pueden darse lugar a que cesen los trabajos de la mina", dicta una orden por la cual los trabajadores del establecimiento pueden seguir desempeñando sus funciones "por encargo particular que interinamente les hago", "sin perjuicio del mérito que produzcan las diligencias de rehabilitación que deberán surtir su efecto conforme al citado decreto [de 14 de noviembre de 1812]", advirtiendo en todo caso que dicha disposición permisiva "no se entiende con los empleados facultativos" (Orden de 15 de diciembre de 1812, AHN, FC-Minas_Almadén, leg. 337, caja primera).

28 La resolución del expediente fue comunicada a las autoridades de Almadén el día 30 de marzo de 1813 por el secretario de Estado de Hacienda, Cristóbal Góngora Delgado (AHN, FCMinas_Almadén, leg. 1134, caja primera, exp. 69, y caja segunda, exp. sin numerar). El listado de los "individuos que debían ser repuestos en los destinos que tenían antes de la invasión de los enemigos", nos muestra -con nombre y apellidos- el organigrama de las Reales Minas de Almadén al final de la guerra (que se corresponde en buena medida con el existente antes de la misma, pues pese a todas las vicisitudes sufridas poco varió durante estos conflictivos años, excepción hecha en las personas que ocupaban los más altos niveles de responsabilidad). 
Un largo y expresivo documento del gobernador y superintendente José Antonio Arenas (en quien Erro había delegado el cargo en abril de 1813) da cuenta de lo sucedido en Almadén el 17 de mayo de ese año 1814, día que llegó la noticia de la abolición de la Constitución: la aclamación popular de Fernando VII, la huida del juez de primera instancia Juan María Ruano (como instrumento que era de aplicación de la Carta Magna gaditana), y el restablecimiento de los plenos poderes sobre la villa y sus Reales Minas en la figura del propio gobernador y superintendente Arenas, que según todos los indicios acaudilló el movimiento popular a favor del retorno al absolutismo por parte del monarca:

"En la villa de Almadén, a 17 de mayo de 1814. El Sr. licenciado José Antonio Arenas, abogado de los Reales Consejos, gobernador y superintendente interino de ella y sus Reales Minas, por ante nosotros los escribanos, dijo:

Que en este día, y a consecuencia de haber llegado por el correo la feliz y muy fauta (sic) noticia de la entrada de S[u] M[ajestad] (Dios le guarde) el Sr. D. Fernando VII en su Corte y Real Palacio, en medio de bendiciones con que le han aclamado cuantos han tenido la dicha de ver su augusta persona, y de haberse remitido por diversos conductos varios impresos y la 'Gaceta extraordinaria de Madrid' con fecha del 12 [de mayo de 1814] en que se contiene el real y grandioso decreto hecho en Valencia a 4 del actual, por el cual nuestro adorado rey, inspirado del cielo y como un ángel tutelar de esta magnánima, fiel y heroica Nación, ha derribado la estatua de Nabuco, el ruinoso edificio y el formidable coloso formado en la insidiosa obra titulada 'Constitución política de la Monarquía' y en los demás decretos de las Cortes; alborozados varios vecinos con tan lisonjeras y venturosas nuevas y dando salida al fuego patriótico que las nuevas instituciones tenían sofocado, después de concurrir a derribar y destruir la lápida de la Constitución, se fomentó el concurso popular, e inflamado del amor que los leales han conservado a su legítimo rey, señor natural, se proclamó por las calles y plazas colocando en el estandarte del Santísimo Sacramento el retrato del deseado Fernando, que fue conducido con el mayor placer por su merced [José Antonio Arenas] y los señores contador [Martín Lorenzo de Cabo] y director de las Minas [José Larrañaga].

Y como, además, la misma reunión popular (creyendo llenar mejor las ideas de S.M.) obligase de un modo irresistible a que las jurisdicciones de los alcaldes constitucionales y juez de primera instancia se reuniesen en este gobierno, de que fueron separadas en fuerza de la Constitución, habiéndose pues verificado así y reasumido su merced 
[el gobernador y superintendente Arenas] la omnímoda jurisdicción en nombre del rey, y bajo la protesta de su real aprobación, siendo consiguiente a este suceso el recogido de causas y papel correspondientes al juzgado para que no se entorpezca la administración de justicia como S.M. desea (...) envió recado al juez que fue de primera instancia [Juan María Ruano] con el infrascrito escribano D. Juan Ruiz Montenegro, manifestándole la necesidad de que entregase las causas para dichos fines, y que al mismo tiempo le dijese que si por el acontecimiento de hoy temiese algún atropello, que desde luego le servirá de asilo la casa de la Superintendencia que habita su merced, a donde se podía trasladar con toda seguridad. (...) [Pero] dicho juez se ha marchado sin hacer entrega formal de las causas ni papeles, ni presentándose ninguna persona en su nombre a efectuarla cual debía...”29.

En las semanas siguientes, tanto los miembros del Ayuntamiento de Almadén elegidos de acuerdo con la Constitución ahora anulada como el juez de primera instancia Ruano (que, como vemos, huye inmediatamente de la villa por miedo a posibles represalias) van a plantear ante el rey una queja frente a la arrogancia y caudillismo del gobernador y superintendente Arenas, actitud tachada por aquéllos de "motín" y de "despojo violento que hizo de la real jurisdicción que regenteaba entonces el Sr. alcalde mayor como juez de letras, y los alcaldes ordinarios D. Alfonso Muñoz y D. Luis Antonio del Salto", aduciendo que "no intervinieron en aquella sublevación sino muy pocos individuos", y que la reclamación contra el gobernador y superintendente la hacían "para conciliar la tranquilidad pública y reintegrar a este heroico pueblo en su buen nombre, que está mancillado por dichos acontecimientos y porque se ha querido tomar la voz del pueblo..." 30 .

29 "Inventario de las causas, expedientes y otros papeles existentes en el despacho del juez de primera instancia de esta villa, practicado el día 17 de mayo del corriente año [1814] con motivo de la repentina marcha del mismo" (AHN, FC-Minas_Almadén, leg. 69, caja primera). En el mismo documento puede leerse que, efectivamente, "como a las seis de la tarde" de ese mismo día 17 de mayo en que se conocían en Almadén los decretos de Fernando VII aboliendo la Constitución, el juez Ruano "había salido a cabo con un criado sin decir a dónde se dirigía".

30 Acuerdo del Ayuntamiento de 1 de agosto de 1814 (Archivo Histórico Provincial de Ciudad Real, leg. 4893, Protocolo de 1814 de Juan Ruiz Montenegro, fols. 199-201). Ese mismo día el Consistorio otorgaba un poder a favor del antiguo superintendente de las Reales Minas, Pedro Hernando, huido en enero de 1810 por causa de la ocupación francesa (al que se titula de "gobernador de Almadén, residente actualmente en la Corte") y de Ramón Quintana (agente de negocios en Madrid), "para que a nombre de esta corporación y sus vecinos feliciten y cumplimenten a S.M., tributándole los mayores obsequios de obediencia y sumisión (...) habiendo sido tan deseada la venida de nuestro amado monarca a la capital de sus reinos a ocupar el trono de sus augustos predecesores" (idem, fol. 204). 
Estas disputas entre el superintendente, el juez de primera instancia (alcalde mayor, según la tradición preconstitucional) y el Ayuntamiento de la villa "sobre quién había de ejercer la real jurisdicción ordinaria y cumplimentar las reales cédulas expedidas para restablecer el gobierno de los pueblos y administración de justicia al estado que tenían en el año 1808", van a inclinarse definitivamente a favor del primero con la reinstauración del "Juzgado de la Superintendencia de las Minas de Almadén” mediante una provisión real fechada el 12 de agosto de 1814, que señalaba de forma taxativa lo siguiente:
"Se restablece el Juzgado de la Superintendencia de esas Minas, con su asesor, en los mismos términos que existían en el año de 1808, cesando cualesquiera otra jurisdicción o juzgado establecido poste- riormente, porque la voluntad de S.M. es que sin detención alguna se reintegren las cosas en Almadén al estado que tenían en dicho año" 31 .

Para la ejecución de tal orden, que volvía a reunir en manos del superintendente los poderes casi omnímodos sobre Almadén y sus Reales Minas con los que contaba con anterioridad al inicio de la Guerra de la Independencia, el Consejo Real libraba otra provisión a favor del superintendente José Antonio Arenas para que, por un lado, hiciese cesar a Juan María Ruano "en el uso y ejercicio de las funciones de juez de primera instancia con el título de letrado, alcalde mayor o cualquiera otro, exigiéndole 200 ducados de multa en caso de resistencia" 32 ; y, por otro lado, para que cesase el Ayuntamiento Constitucional "y se repusiesen todas las autoridades y funcionarios públicos al estado que tenían en el citado año de 1808, conforme a lo prevenido en la Real Cédula de 30 de julio último" 33 .

31 Real provisión firmada por el entonces secretario de Estado y del despacho de Hacienda, Cristóbal Góngora Delgado, de la que se toma razón en la Contaduría de las Minas el día 20 de agosto, y que se comunica también a la Secretaría del Despacho de Gracia y Justicia y al Consejo Real (AHN, FC-Minas_Almadén, leg. 1453, caja primera, documento $2^{\circ}$ número 46 del año 1814). Por su parte, mediante Real Orden de 6 de septiembre de ese mismo año 1814 se procedía también a restablecer el Tribunal de la Superintendencia General de Azogues, institución del Gobierno central ante la que debía rendir cuentas el superintendente del establecimiento minero de Almadén (AHN, Consejos, leg. 20196, exp. 3).

32 Provisión del Consejo Real recogida en el "Certificado de enero de 1815 de Miguel Calvo García, escribano de cámara del rey nuestro señor en la Sala de Alcaldes de Casa y Corte y encargado del despacho de la de Gobierno de la misma" (AHN, FC-Minas_Almadén, leg. 69, caja primera, documento sin fecha [enero de 1815]).

33 Por Real Cédula de 30 de julio de 1814 Fernando VII mandaba que "que se disuelvan y extingan los Ayuntamientos y alcaldes constitucionales, [y] que se establezcan los Ayuntamientos, Corregimientos y alcaldes mayores en la planta que tenían en el año de 1808 ". 
Pese a tales resoluciones (y también, en buena medida, a causa de las mismas), que volvían a colocar a la figura del gobernador y superintendente como autoridad suprema de Almadén y sus Reales Minas, a mediados de 1814 la situación en la villa distaba de ser pacífica, y no lo estará hasta bastantes meses más tarde, lo que indica que seguían vivas las rencillas surgidas entre sus principales autoridades durante el conflicto bélico iniciado en 1808. Así nos lo demuestra un documento dirigido todavía un año más tarde por el secretario universal de Indias Miguel de Lardizábal y Uribe al gobernador y superintendente de Almadén, sugiriéndole que "procure reconciliar los ánimos de los empleados en ese establecimiento, para que unidos contribuyan a las mejoras y adelantamientos de que es susceptible" 34 .

De hecho, podríamos decir que la situación generada por la guerra no comenzará a "normalizarse" en Almadén hasta la reposición en el cargo de gobernador y superintendente de quien lo había sido con anterioridad a la ocupación francesa de la Península, Pedro Hernando, lo que se llevará a cabo mediante una Real Orden de 30 de julio de 1815, de la que se tomó razón en la Contaduría de las Minas el 5 de agosto siguiente $^{35}$. Hernando se reintegraría efectivamente en su cargo el 15 de septiembre de 1815, día de su regreso a Almadén tras su huida acaecida más de cinco años antes, en la víspera del incontenible ataque de las tropas francesas encabezadas por el mariscal Victor camino de Andalucía.

Unos meses más tarde de la vuelta del superintendente Hernando, el Ayuntamiento de Almadén ofrecía su gratitud a Fernando VII por haber devuelto finalmente la tranquilidad a la villa. Y lo hacía mediante un memorial fechado el 9 de abril de 1816, dando por cerradas las heridas abiertas a raíz de la ocupación francesa:

"Señor. Vuestra villa de Almadén no correspondería a la particular predilección con que V.M. -así como sus augustos predecesores- se ha dignado mirarlas desde su feliz advenimiento al trono, si ahora más que nunca no le tributara por medio de su Ayuntamiento el más respetuoso homenaje de gratitud, cuando ve restituida entre sus vecinos aquella unión y armonía que con dolor ha visto interrumpida por algún tiempo.

34 Documento fechado en Madrid el día 5 de julio de 1815 (AHN, FC-Minas_Almadén, leg. 1453, caja segunda, documento 67 de 1815).

35 La Real Orden de 30 de julio de 1815 había sido comunicada por el secretario universal de Indias Miguel de Lardizábal al hasta entonces superintendente y gobernador de Almadén José Antonio Arenas, agradeciéndole los servicios prestados ("debe estar vuestra merced seguro de que su majestad está muy satisfecho del extraordinario mérito que ha contraído V.M. en el desempeño del gobierno interino del mismo". AHN, FC-Minas_Almadén, leg. 1453, caja segunda, documento 80 del año 1815). 
El Ayuntamiento ve, lleno de complacencia, unidos con el mayor celo por el mejor servicio de V.M. al jefe principal [director de las Reales Minas], los jefes parciales de los diferentes ramos de la administración, y cooperar con el no menor [celo] por la prosperidad de este vuestro real establecimiento [y] por la felicidad de un pueblo que tiene la dicha de ser el depositario de la preciosa joya que tiene V.M. en sus Reales Minas de azogue; ve a los subalternos seguir a competencia el ejemplo de sus respectivos jefes; ve a los trabajadores dedicarse con alegría al duro y penoso ejercicio de las minas, bajo de unos jefes que justamente han merecido su confianza; ve, en fin, a todos los habitantes felicitarse los unos a los otros y bendecir la soberana mano de V.M., que con sus sabios decretos se ha dignado volverles los serenos días que con ansia apetecían..." ${ }^{36}$.

\section{RELACIÓN DE SIGLAS EMPLEADAS}

ACD: Archivo del Congreso de los Diputados.

AGI: Archivo General de Indias.

AHMA: Archivo Histórico Municipal de Almadén.

AHN: Archivo Histórico Nacional.

AHP-CR: Archivo Histórico Provincial de Ciudad Real.

36 AHMA, leg. 38, Libro de actas del Ayuntamiento de Almadén de 1816. El secretario de Estado de Hacienda, Manuel López Araujo, agradece en nombre del rey tales palabras de alabanza mediante misiva dirigida al Ayuntamiento de Almadén el día 26 del mismo mes de abril de 1816 (idem). 


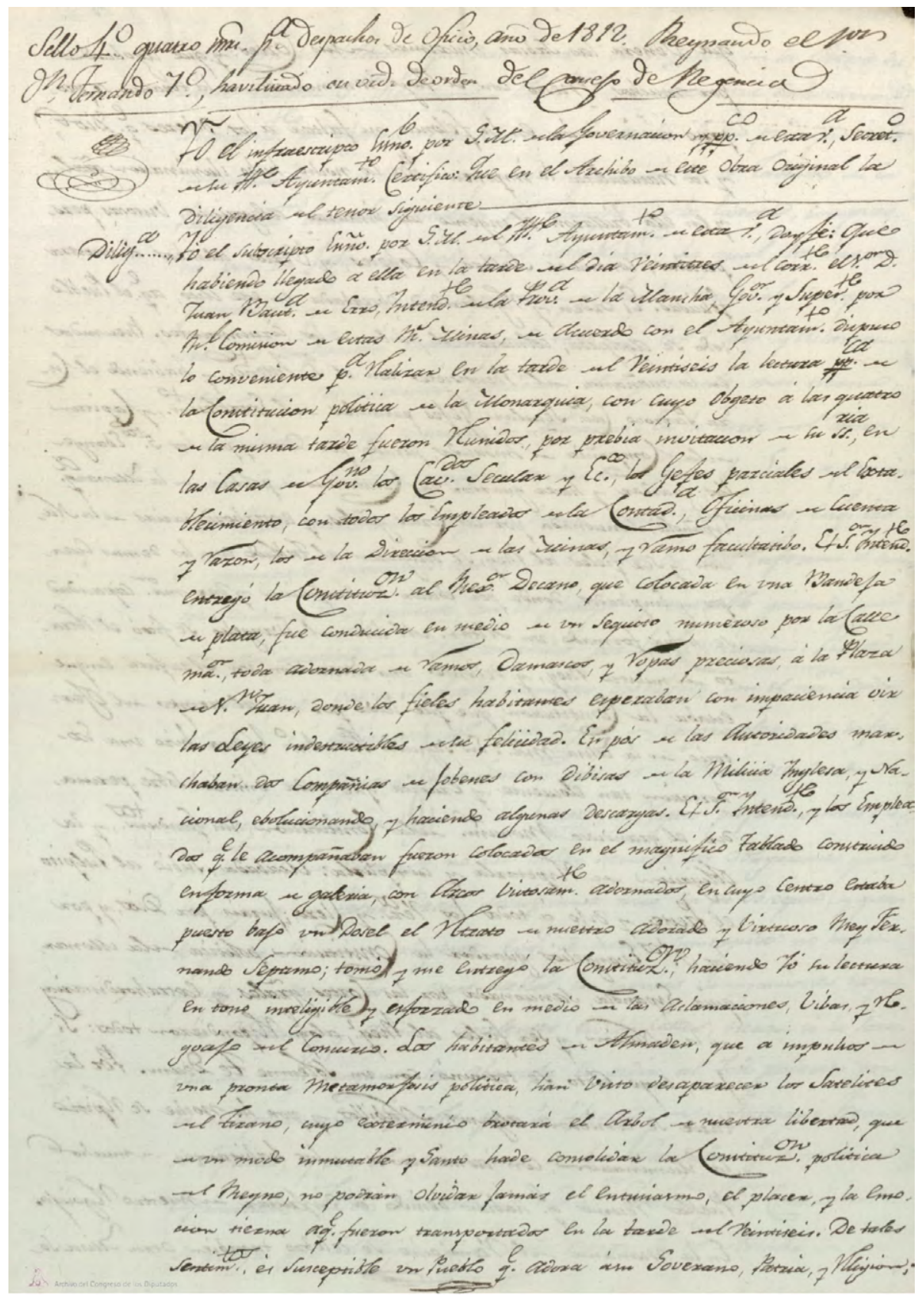




\section{ANEXO \\ Transcripción del acta de la jura de la Constitución de 1812 en Almadén}

"Yo, el subscripto escribano por S. M. del ilustre Ayuntamiento de esta villa, doy fe: que habiendo llegado a ella en la tarde del día veintitrés del corriente el Sr. D. Juan Bautista de Erro, intendente de la provincia de La Mancha, gobernador y superintendente por Real comisión de estas Reales Minas, de acuerdo con el Ayuntamiento dispuso lo conveniente para realizar en la tarde del veintiséis la lectura pública de la Constitución política de la Monarquía, con cuyo objeto a las cuatro de la misma tarde fueron reunidos por previa invitación de su señoría en las casa de gobierno los cabildos secular y eclesiástico, los jefes parciales del establecimiento con todos los empleados de la Contaduría, oficinas de cuenta y razón, los de la Dirección de las Minas y ramo facultativo. El Sr. intendente entregó la Constitución al regidor decano, que, colocada en una bandeja de plata, fue conducida en medio de un séquito numeroso por la calle mayor, toda adornada de ramos, damascos y ropas preciosas, a la plaza de San Juan, donde los fieles habitantes esperaban con impaciencia oir las leyes indestructibles de su felicidad. En pos de las autoridades marchaban dos compañias de jóvenes con divisas de la milicia inglesa y nacional, evolucionando y haciendo algunas descargas.

El Sr. intendente y los empleados que le acompañaban fueron colocados en el magnífico tablado construido en forma de galería, con arcos vistosamente adornados, en cuyo centro estaba puesto bajo un dosel el retrato de nuestro adorado y virtuoso rey Fernando Séptimo; tomó y me entregó la Constitución, haciendo yo su lectura en tono inteligible y esforzado en medio de las aclamaciones, vivas y regocijo del concurso. Los habitantes de Almadén, que a impulsos de una pronta metamorfosis politica han visto desaparecer los satélites del tirano,[de] cuyo exterminio brotará el árbol de nuestra libertad que de un modo inmutable y santo ha de consolidar la Constitución politica del reino, no podrán olvidar jamás el entusiasmo, el placer y la emoción interna a que fueron transportados en la tarde del veintiséis. De tales sentimientos es susceptible un pueblo que adora a su soberano, patria y religión, 


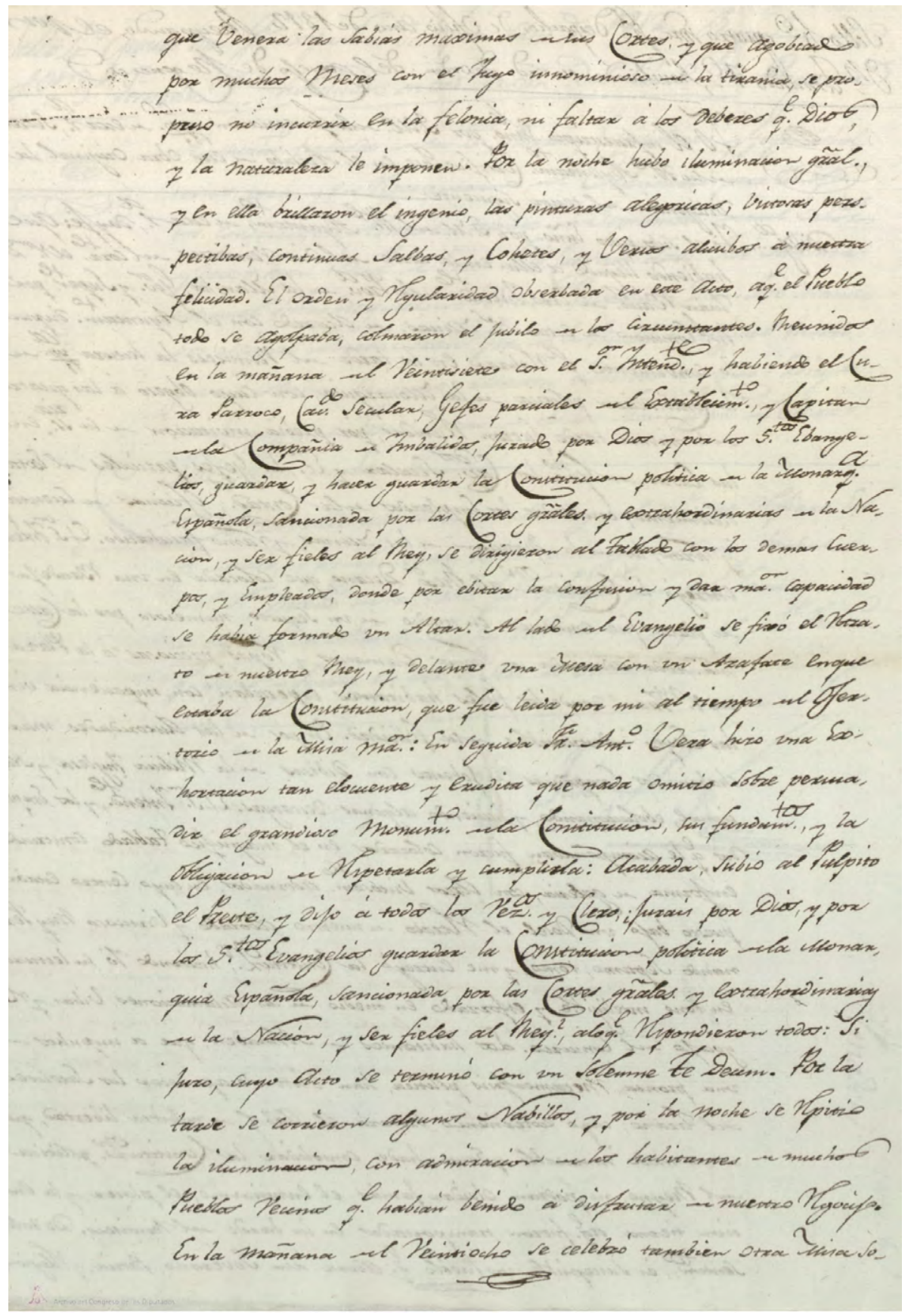


que venera las sabias máximas de sus Cortes y que, agobiado por muchos meses con el yugo ignominioso de la tiranía, se propuso no incurrir en la felonía ni faltar a los deberes que Dios y la naturaleza le imponen. Por la noche bubo iluminación general, y en ella brillaron el ingenio, las pinturas alegóricas, vistosas perspectivas, continuas salvas $y$ cohetes y versos alusivos a nuestra felicidad. El orden $y$ regularidad observada en este acto, a que el pueblo todo se agolpaba, colmaron el júbilo de los circunstantes.

Reunidos en la mañana del veintisiete con el Sr. intendente, y habiendo el cura párroco, cabildo secular, jefes parciales del establecimiento y capitán de la Compañía de Inválidos jurado por Dios y por los Santos Evangelios guardar y hacer guardar la Constitución política de la Monarquía Española sancionada por las Cortes Generales y Extraordinarias de la nación, y ser fieles al rey, se dirigieron al tablado con los demás cuerpos y empleados, donde por evitar la confusión y dar mayor capacidad se habia formado un altar.

Al lado del Evangelio se fijó el retrato de nuestro rey, y delante una mesa con un azafate en que estaba la Constitución, que fue leída por mí al tiempo del ofertorio de la misa mayor. Enseguida fray Antonio Vera hizo una exhortación tan elocuente y erudita que nada omitió sobre persuadir el grandioso monumento de la Constitución, sus fundamentos y la obligación de respetarla y cumplirla. Acabada, subió al púlpito el preste y dijo a todos los vecinos y clero: '¿juráis por Dios y por los Santos Evangelios guardar la Constitución política de la Monarquía Española, sancionada por las Cortes Generales y Extraordinarias de la nación, y ser fieles al rey?'. A lo que respondieron todos: 'Sí, juro'. Cuyo acto se terminó con un solemne Te Deum. Por la tarde se corrieron algunos novillos, y por la noche se repitió la iluminación, con admiración de los habitantes de muchos pueblos vecinos que habian venido a disfrutar de nuestro regocijo. En la mañana del veintiocho se celebró también otra misa 


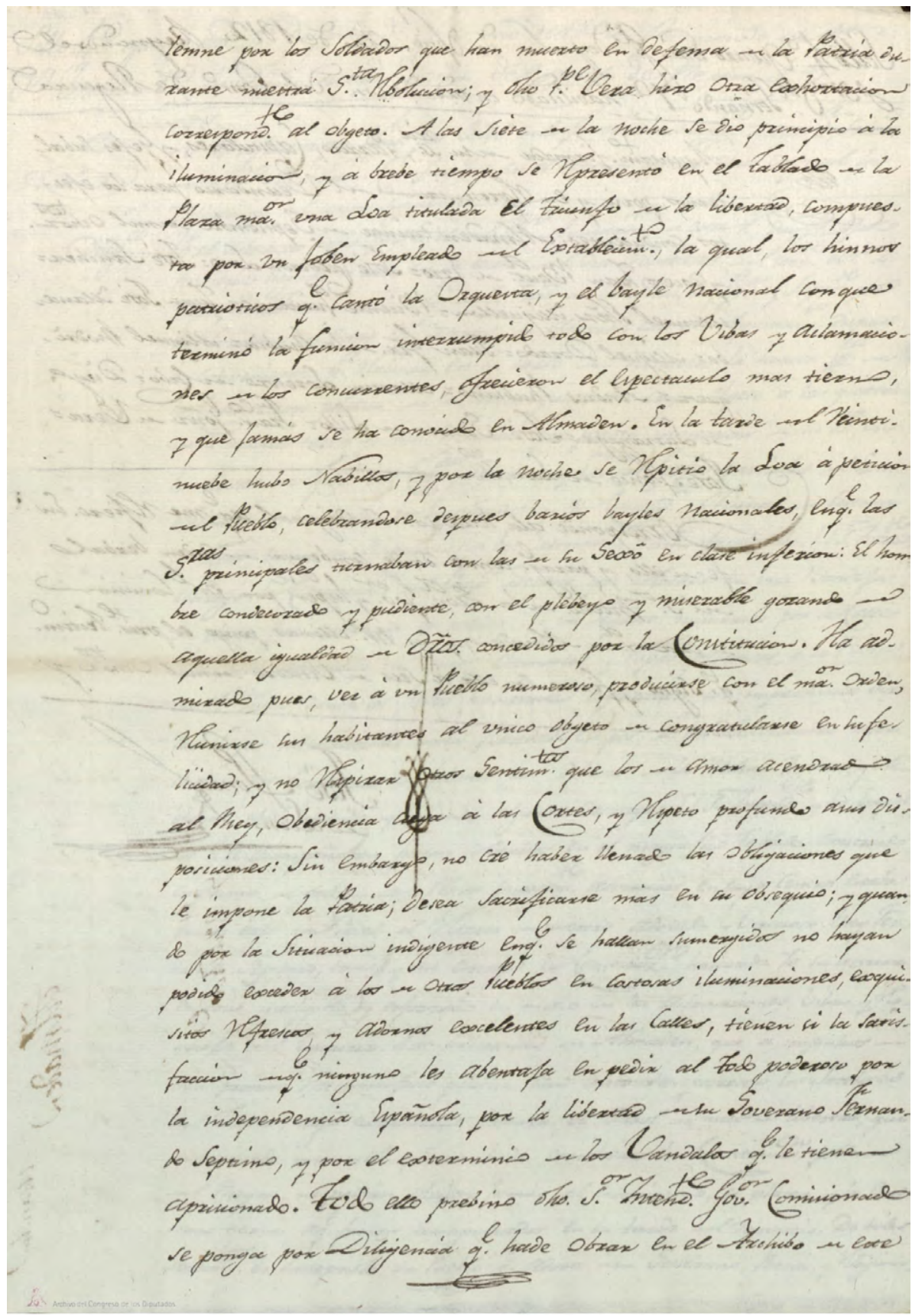


solemne por los soldados que han muerto en defensa de la patria durante nuestra santa revolución, y dicho preste Vera bizo otra exhortación correspondiente al objeto. A las siete de la noche se dio principio a la iluminación y a breve tiempo se representó en el tablado de la plaza mayor una loa titulada 'El triunfo de la libertad', compuesta por un joven empleado del establecimiento, la cual, [además de] los bimnos patrióticos que cantó la orquesta y el baile nacional con que terminó la función, interrumpido todo con los vivas y aclamaciones de los concurrentes, ofrecieron el espectáculo más tierno y que jamás se ha conocido en Almadén. En la tarde del veintinueve hubo novillos, y por la noche se repitió la loa a petición del pueblo, celebrándose después varios bailes nacionales en que las señoras principales turnaban con las de su sexo de clase inferior. El hombre condecorado y pudiente, con el plebeyo y miserable, gozando de aquella igualdad de derechos concedidos por la Constitución. Ha admirado, pues, ver a un pueblo numeroso producirse con el mayor orden, reunirse sus habitantes al único objeto de congratularse en su felicidad, y no respirar otros sentimientos que los de amor acendrado al rey, obediencia ciega a las Cortes y respeto profundo a sus disposiciones. Sin embargo, no cree haber llenado las obligaciones que le impone la patria, [y] desea sacrificarse más en su obsequio. Y [aun] cuando por la situación indigente en que se hallan sumergidos no hayan podido exceder a los de otros pueblos en costosas iluminaciones, exquisitos refrescos y adornos excelentes en las calles, tienen si la satisfacción de que ninguno les aventaja en pedir al Todopoderoso por la independencia española, por la libertad de su soberano Fernando Séptimo y por el exterminio de los vándalos que le tienen aprisionado. Todo ello previno dicho Sr. intendente gobernador comisionado se ponga por diligencia, que ha de obrar en el archivo de este 


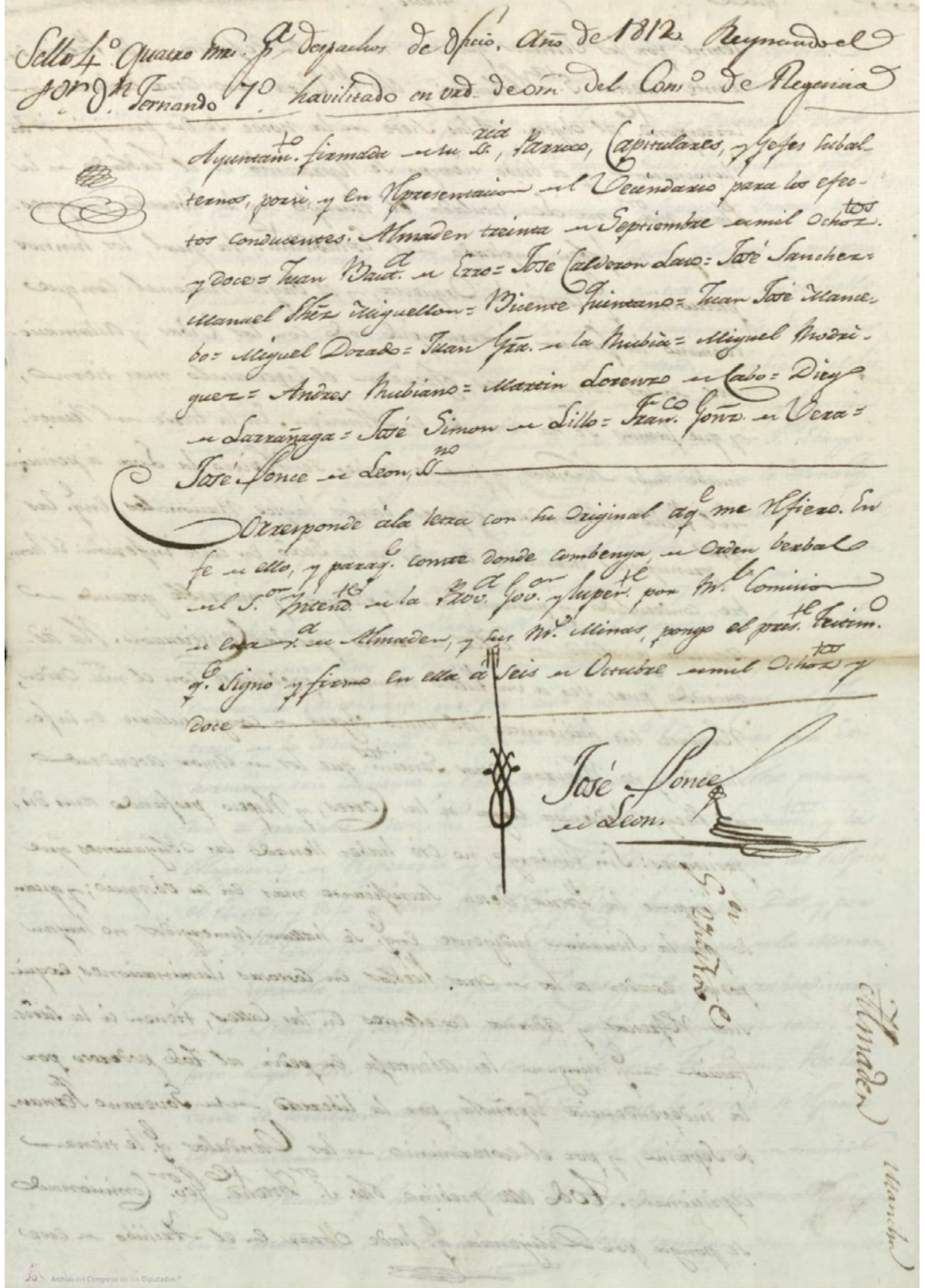


Ayuntamiento firmada de su señoría, párroco, capitulares y jefes subalternos, por sí y en representación del vecindario, para los efectos conducentes.

Almadén, treinta de septiembre de mil ochocientos y doce.

[Firmado por:] Juan Bautista Erro. José Calderón Laso. José

Sánchez. Manuel Sánchez Miguellón. Vicente Quintano. Juan José Mancebo. Miguel Dorado. Juan García de la Rubia. Miguel Rodríguez. Andrés Rubiano. Martín Lorenzo de Cabo. Diego de Larrañaga. José Simón de Lillo. Francisco González de Vera. [Y por] José Ponce de León, escribano”.

(Archivo del Congreso de los Diputados) 
